Journal of Social Sciences (COES\&RJ-JSS)

ISSN (E): 2305-9249 ISSN (P): 2305-9494

Publisher: Centre of Excellence for Scientific \& Research Journalism, COES\&RJ LLC

Online Publication Date: $1^{\text {st }}$ January 2017

Online Issue: Volume 6, Number 1, January 2017

http://centreofexcellence.net/J/JSS/JSS\%20Mainpage.htm

\title{
Promoting the Higher Education Excellence in Jordan: Factors Influencing Learner Attitude toward E-Learning Environment Based on the Integrated Platform Mohammad Khasawneh \\ The World Islamic Sciences and Education University, Jordan,
}

\begin{abstract}
Electronic learning (e-learning) is considered in a beginning stage in the developing nations such as Arab world especially in the field of higher education system. Jordan as one of the developing nation though appreciates the importance of universities and their role in achieving an economic prosperity through the growth of human resources; unfortunately, the adoption of e-learning is quite low among the students in the Jordanian universities. This study therefore, is concerned with the improvement of educational process through the adoption of e-learning tools among the students in the Jordanian higher education institutions. The main purpose of this study is to examine the potential prominent factors related to the adoption and usage of Information and Communication Technology (ICT) in the Jordanian public universities among the students. The main challenge of the study is to provide such an understanding on the e-learning usage by applying the Technology Acceptance Model (TAM), Diffusion of Innovation (DOI) theory, and Decomposed Theory of Planned Behaviour (DTPB). A self-administrated survey was conducted on 350 of students selected from public universities in Jordan. A total of 253 participants (72\%) have responded, and series of data analyses of variables measurement for reliability and validity test of predictors were performed. The results of the analysis, however, contribute a new model which is considered as a novel model in such studies. The findings show that Attitude towards Technology (ATT), have positively affected the Behavioural Intention (BI) to use technologies in the higher educational system among students. Moreover, there is a significant relationship between students' perception of technology characteristics and their ATT using the e-learning technologies in the higher education system.
\end{abstract}

\section{Keywords:}

E-learning, Adoption theories, Higher Education Institutions, Attitude, Jordan.

\section{Citation:}

Khawaseneh, Mohammad (2017); Promoting the Higher Education Excellence in Jordan: Factors Influencing Learner Attitude toward E-Learning Environment Based on the Integrated Platform; Journal of Social Sciences (COES\&RJ-JSS), Vol.6, No.1, pp: 139155. 


\section{Introduction}

Information technology plays an important role in modern institutions by facilitating and improving the teaching and learning process to accompany the information age (Amara and Atia, 2016). There are many definitions of E-learning, Jenkins and Hanson (2003) defined it as learning facilitated, enhanced, and supported through the utilization of ICTs. Based on this definition, e-learning concept is the use of ICTs such as (Internet, computer, telephone, radio, video, and others) to support educational system. According to the Internet World Stats in June 2016, the number of Internet users in the Jordan approximately equals $5,700,000$, which is mean $73.6 \%$ of Jordanian population. The importance of using Internet in Jordan has risen in many sectors such as higher education. By a variety of measures, Internet is a necessary tool of almost college student's life (Alshammari, 2014). As this technology diffusion procedure is often the economic lever upon which national competitive advantage will reside, e-learning provides the manpower to achieve this high technology advantage. In striving towards a competitive institution, a university must improve the educational system related to the rapidly advance of information technology in this field (Singh, 2015; Ramirez, Byrkjeflot, and Pinheiro, 2016). Hence, the universities in developing nations as well as in developed countries attempt to move in parallel with the rapid advancements of ICT by increasing the usage of e-learning as a tool to improve the educational system and to become more flexible by reducing some difficulties in the education process. In relation, the Jordanian Ministry of Higher Education and Scientific Research (MoHESR) emphasizes to adopt the Royal Message in the Higher Education Development Forum (HEDF), and the Jordanian National ICT Agenda which emphasize the adoption and usage of e-learning in the Jordanian universities to improve the educational process. Therefore, improving the quality of the teaching and learning process in these institutions is the main goal of the leadership of higher education (MoHESR, 2016). In April 2014, Jordan government established "The National Commission for Human Resources Development" (NCHRD), and in September 2016 His Majesty the King Abdullah II patronize its recommendations in the national conference. National ICT Agenda in higher education strategy was ratified in a national conference, and was approved by the council of the higher education in Jordan. The strategy aims to encouraging students, academic staff, and universities management in employing technologies, and improving their skills, knowledge, and capabilities that improving the teaching and learning process.

Consequently, understanding the factors that may affect students to adopt and usage of elearning system can help higher education leader in applying special strategies to attract students in adopting this technologies (Park, 2009). On the other hand, there is a gap in the research for the developing nations that empirically identifies the synergy among psychological and cognitive factors that may influence students' BI in using e-learning mode (Chang, Mak, Li, Wu, Chen, and $\mathrm{Lu}, 2011$ ). The current research focuses on the perceived adoption and usage of the e-learning in order to identify common factors that can affect it. The research also attempts to contribute to the existing evidence regarding the adoption theories such as TAM, DOI, and DTPB across cultural differences. The research mainly focuses on the role of learning styles in Jordanian universities in order to understand the feasibility of electronic education system in accordance with this psychological, technological, and cultural trait. 


\section{Problem Statement}

The study, therefore, applies the TAM (Davis, 1989), DOI (Rogers, 1995), and DTPB (Taylor and Todd, 1995) theories to develop a suitable model to achieve its objectives. Besides, there are two main factors which were used to develop the model, the intention to use or reject e-learning tools among the students in Jordanian universities, and their attitude toward using it in the educational process.

\section{Behavioural Intention (BI)}

BI refers to a person's subjective probability in performing certain behaviour (Ajzen and Fishbein, 1980). It decides if the students want to accept and use the e-learning in the educational system or reject it (Shiau and Chau, 2016). BI is considered the critical factor that affect student's subjective probability to adopt e-learning in their teaching and learning process (Swaim, Maloni, Napshin, and Henley, 2014). Park, Lee and Cheong (2008) argued that the BI is very important factor that affects students to use the InternetBased Course Management System (IBCMS). In relation, Macharia and Nyakwende (2010) confirm the importance of measuring BI in the using and adoption of ICT in the universities. BI, however, is considered a very important factor to the study because its ultimate station to accept or reject the e-learning system in the educational system among students.

\section{Attitude towards Technology (ATT)}

Attitude refers to an individual's perception or general feeling of favourableness or unfavourableness towards using innovation (Ajzen and Fishbein, 1980). It's referring to student feeling of favourableness or not towards using e-learning in the educational system (Lam, Cho, Qu, 2007). Park (2009) mentions that it is necessary to conduct studies that deal more intensively with students' perceptions of attitude towards, and intention to use educational technologies. Consequently, the relationship between the ATT and the BI to adopt and use e-learning implies that, other factors being equal, student tend to perform behaviours toward which they have positive attitudes (Sharma and Jacobs, 2016).

Several studies have discus the significance of the relationship between ATT and BI to use e-learning and other technologies such as (Talukder, 2014; Sharma and Jacobs, 2016). In Jordan, a study by Qudais, Al-Adhaileh, and Al-Omari (2010) presents the relationship between both factors (ATT and BI) is significantly important. The ATT, however, plays a critical role to success this study because it measures the BI to accept or reject e-learning system among student in Jordanian universities.

From the above paragraph and reviewing the literatures in the adoption of technologies in the information system field, e-learning system in particular, the study determines the problem statement as "the lack of adoption and usage of e-learning in the Jordanian universities among students in their learning system". In order to solve the problem, the study measures students' perception of the e-learning technologies by studying their perception of ATT, which affect on their BI to adopt or reject these educational technologies.

\section{Literature Review}

\section{ICT in the Arab World}

The Arab world consists of twenty two countries, all of them under the league of Arab states. ICT was introduced in the Arab world in the early 1960. In that era, the efforts of 
Arab countries were focused on utilization of information system tools and translating them into the Arabic language. This encourages the information technology companies to produce Arabic software product. The result of this effort created an Arabic computer standardized code, which was founded in 1985 by the Arab Standards and Metrology Organization (ASMO), and Arabization coordination bureau specialized organizations under the Arab league (Goodman and Green, 1992).

ICT becomes a major factor in the world that drives social, economic and human development, in addition to the higher education institutions (Duţăa and Martínez-Rivera, 2015). The rapidly growing use of ICT and the Internet by the government, nongovernment, and individuals in the Arab world has changed many things from the traditional to the digital world. Hence, the development of an ICT strategy is vital for the growth of the knowledge economy in developing countries. Consequently, in the past three decades, the ICT industry has grown to be a driving force behind the world economy and gaining the attention of the national leaders (Intaj, 2010). In relation, Jordan as one of the developing countries tries to become a leader in the Arab world by using ICT in all sectors, particularly in education and higher education sectors, in which, Jordan is considered to have one of the best systems in the Arab world (Al-Zaidiyeen, Mei, and Fook, 2010).

Many ICT adoption studies have been widely done in the developed nation, yet there is insufficient knowledge regarding ICT adoption in the developing countries and in the Arab world particularly. However, the adoption and usage of new technologies in the Arab world is still at its very early stages in comparison to other countries in North America, Europe, and other developing countries (Al-Zaidiyeen et al., 2010; Qudais et al., 2010; Khasawneh and Ibrahim, 2012; Khasawneh, 2016). Many countries in these regions are still lagging far behind the developed countries in terms of the acceptance of technologies, and many organizations in these regions are not yet ready to accept the ICT (Demeke, Olden, and Nocera, 2016). The lack of basic infrastructure, senior management support, sufficient funds, enthusiasm about ICT adoption, level of education and skills, expertise in the field, and the resistance to anything which is new, unclear, and uncertain all impede the adoption of the new technologies and innovations (Khasawneh, 2015; Othman, 2016).

\section{Behavioural Intention (BI)}

Adoption of information system and technologies is very important in the social sciences field such as management information system discipline (Baskerville and Myers, 2002). It is focusing on the person's BI which is considered the most determinant in adopting or rejecting the technologies. Davis (1989) argues that intention is the determinant factor of the theoretical foundation in information system researches by individual behaviour to use or not use the technology. In conjunction, many of adoption theories consider behavioural beliefs, normative beliefs, and external factors affect personal attitudes toward new technologies such as (TAM, DOI, and DTPB) which consequently affect individuals' adoption or usage the new technologies. The link between ATT and BI to adopt the innovation is well recognized and strongly supported in the literature (Lam et al., 2007). Consequently, the notion that BI can affects on the actual use of new technologies and innovations is supported (Ahmad, Tarmidi, Ridzwan, Hamid, and Roni, 2014; Songkram, 2015; Truskolaska, Luka, Toruj, Wrona, Smagowska, 2015). 
By definition, intention is defined as the "person's location on a subjective probability dimension involving a relation between himself and some action", while BI is "a person's subjective probability that he will perform some behaviour" (Ajzen and Fishbein, 1980). In response to these definitions, most of adoption theories such as, TAM, DOI, and DTPB, incorporate the individual's BI to adopt the technologies as the main factor. Specifically, TAM suggests that the BI to use technology could have been determined factor by the individual's ATT and the Perceived Usefulness (PU), in addition to the Perceived Ease of Use (PEOU). Therefore, the equation of the BI in TAM become as BI= ATT + PU + PEOU (Davis, 1989). Sequentially, Rogers (1995) proposes that the DOI depends on the knowledge about the technology itself which can possess from the social system, followed by the characteristics of the individuals and technologies which are influenced factors of the BI to take the decision of adoption. On the other hand, DTPB introduces BI as a combined factor of individual's ATT and Subjective Norms (SN), in addition to the Perceived Behavioural Control (PBC) factor, or simply BI=ATT + SN+ PBC (Taylor and Todd, 1995). However, this study considers the BI as the main dependant variable and the key for students to adopt the e-learning. In conjunction, ATT also affects students' BI to adopt and use e-learning system. The study concerns on five independent factors derived from TAM, DOI, and DTPB, which are PU, PEOU, Trialability (TRIAL), Observability (OBSERV), and Computer Self-Efficacy (CSE).

\section{Attitude towards Technology (ATT)}

Construct definition refers to "an individual's perception or general feeling of favourableness or unfavourableness towards using technologies" (Ajzen and Fishbein, 1980; Rogers 1995; Tan and Todd, 2000). Attitude takes a special interest from the researchers in the fields of the adoption in general, and information technology in particular. In fact, ATT is considered as one of the main influential factors which, affecting students or other individuals to adopt or reject a certain technology. This section explains how ATT affects the students to adopt and use e-learning system in their educational system. Ajzen (2002) refers that most studies which are interested in the adoption of innovation from attitudinal factors were conducted based on the structure of the DTPB. With the broad expansion of technologies in educational system during the last decade, many studies have explored the attitudes educators or students towards the adoption of e-learning in education (Gasaymeh, 2009).

Actually, many researchers defined attitude in different perspectives and it is very hard to get one definition of attitude (Walker and Johnson, 2005). However, attitude is quite challenging to any studies because any definition must explain the nature of the concept being defined (Erwin, 2001). This study focuses on the definitions of the attitude, which are given within the adoption theories as well as compatible with the information system research. Davis (1993) considered the attitude towards using the new system or innovation as "the assessment of the result that an individual perceived it when he/she use the system in his/her job". Correspondingly, Rogers (1995) defines attitude as the "individual's forms favourable or unfavourable attitude toward innovation", and also pointed out the attitude formation in the persuasion phase. The main result of the persuasion phase in the adoption of an innovation is the decision of the individual favourable or unfavourable attitude towards the innovation (Rogers, 1995).

Sequentially, the literature shows that attitude is considered one of the most influencing factors for students' BI to adopt the educational technologies. This study focuses on the 
students' ATT in Jordanian public universities because it has a positively significant relationship with their BI to use e-learning system (Songkram, 2015; Truskolaska et al., 2015). As a result, students' ATT are considered as a major predictor of using new technologies in the educational system (Tran, 2013; Valsamidis, Kazanidis, Petasakis, Kontogiannis, and Kolokitha, 2014). Thus, students' attitudes towards computer can play important roles in the adoption and actual use of e-learning. In conjunction, Jordan found that attitude is significantly important for the students' BI to using educational technologies (Qteishat, Alshibly, and Al-Ma'aitah, 2013; Almarabeh, Majdalawi, and Mohammad, 2016).

\section{Technology Characteristics}

The rapidly advancement of technologies and Internet in many sectors, educational sector in particular, and especially higher education institutions, enhances the level of educational systems around the world (Qteishat et al., 2013). It is very important to perceive the attributes of the technologies itself among the potential adopters whom are considered the most receptive of the new technologies. The characteristics of e-learning are considered one of the reasons that affect the adoption rate by the students who adopt or reject it (Liaw and Huang, 2013). Accordingly, Davis, 1989; Rogers, 1995; and Taylor and Todd, 1995, in their theories (TAM, DOI, and DTPB respectively) argue that the perceived technology characteristic is very significant in clarifying the rate of adoption of the technology. Thus, this study focuses on five technological factors which have influences on the adoption and use of e-learning system and derived from TAM, DOI, and DTPB, which are PU, PEOU, TRIAL, OBSERV, and CSE, defined as follows;

(i) Perceived usefulness is a well-recognized factor used by TAM and defined as "the degree to which an individual believes that using a particular innovation would enhance his or her job performance." (Davis, 1989). By studying previous literature in elearning adoption and usage, the researcher found that PU has a significant direct effect on attitude towards using an e-learning system (Cheng, 2011; Tselios, Daskalakis, Papadopoulou, 2011; Hsieh, Lu, and Lee, 2014). In conjunction, many studies argue that there is a strong relationship between PU of new technologies of students and their attitude and intention to adopt and use it (Lu and Lin, 2012). Park (2009) attempted to predict students' intention to use e-learning system in a Korean university, one of the determinate factors is the PU of e-learning. In addition, Tarhini, Hone, Liu, and Tarhini, (2016) present that the PU is affected learners' attitude and intention to adopt and use of elearning system.

(ii) Perceived ease of use is defined as "the degree to which a person believes that using a particular system would be free from effort" (Davis, 1989; Schneberger, Amoroso and Durfee, 2008). Based on TAM, many previous studies in e-learning adoption found that PEOU has a significant direct effect on attitude towards using an elearning system (Park, 2009; Cheng, 2011; Tselios et al., 2011; Hsieh et al., 2014). In addition, previous literature examines the process of acceptance and usage of electronic courseware by university instructors. The collected data indicate that PEOU affected BI for the students to use the electronic courseware (Park, Lee and Cheong, 2008).

(iii) Trialability is defined as "the degree to which an innovation may be experimented with on a limited basis" (Rogers and Shoemaker, 1971). There are many studies have been adopted DOI theory to explore influencing factors of e-learning intention, one of these factors is TRIAL (Duan, He, Feng, Li, and Fu, 2010; Lee, Hsieh, and Hsu, 2011; Sawang, Newton, and Jamieson, 2013). Based on DOI, many previous 
studies in e-learning adoption found TRIAL has a significant effect on attitude towards using an e-learning system (Duan et al., 2010; Lee et al., 2011).

(iv) Observability is defined as "the degree to which the results of an innovation are visible to others" (Rogers, 1995). Rogers argues that the perceived observability of an innovation or technology is considered positively influencing related to the rate of adoption and diffusion, which is argued by Sooknanan (2002). However, researchers argue that DOI factors influencing the students' BI to adopt and use e-learning in the educational system. Consequently, OBSERV shows a strong relationship that influence students' attitude and BI to adopt the e-learning system (Duan et al., 2010; Lee et al., 2011; Sawang et al., 2013).

(v) Self-efficacy refers to a belief and confidence that an individual perceives that he has ability to complete certain tasks successfully (Bandura, 2005). IT researchers have defined CSE as self evaluation of individual ability to apply computer skills and talents to complete particular tasks (Compeau and Higgins, 1995). Students' ability to learn by their own pace is a key point for adoption and usage of e-learning, so CSE is very significant factor to adopt e-learning (Lee, and Mao, 2016). However, previous studies argued that influencing students' intention to adopt e-learning include CSE factor (Alenezi, Abdul Karim, and Veloo, 2010; Cheung and Vogel, 2013; Dae-sik and Jeong-kyoum, 2013). Thus, students with high CSE are more confident of adoption and usage e-learning. Therefore, CSE can directly affect adoption of e-learning among students' attitude and BI. Therefore, these five attributes might not influence the rate of adoption of e-learning in all cases. In other words, some of these factors are considered significant to one case but may irrelevant to other. However, this study utilized determinant factors to discover the affected factors for the students in using the technologies in the educational system.

\section{Research Model and Hypotheses}

The previous literature explore that the BI to use technologies such as e-learning is considered the main dependant factor in the adoption theories such as Theory of Reasoned Action (TRA), Theory of Planned Behaviour (TPB), DTPB, TAM, and the DOI, in addition to external variables such as ATT, SN and PBC (Ajzen, 1991; Taylor and Todd, 1995). Therefore, this study adopts the TAM, DOI, and DTPB to build the research model. The study is conducted on students in the Jordanian public universities to identify the relations between their beliefs to use e-learning system in the educational system. Figure 1 presents the proposed the model of research which contains the main factors that could have influenced the adoption of e-learning in the educational system among students in Jordanian higher education institutions.

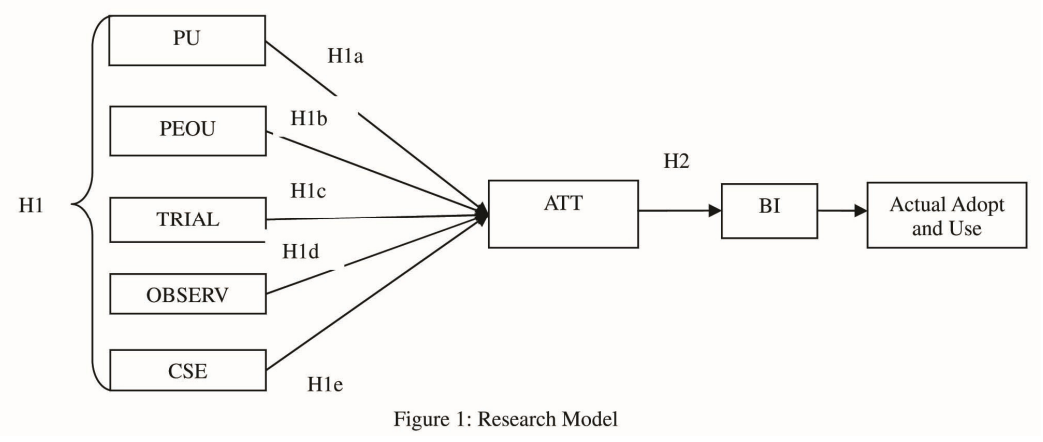


On the other hand, figure 1 presents the hypotheses of the study, the main goal of these hypotheses is to help the researcher to find and explain the relationship between the factors that are proposed in the research model (Sekaran, 2003). In this research, hypotheses are intended to measure the positive or negative relationship among factors that would determine the students' ATT and BI to use e-learning system in their educational system.

With regards to Davis (1989), Rogers (1995), and Taylor and Todd (1995), this study argues that the greater the PU, PEOU, TRIAL, OBSERV, and CSE of using e-learning in the educational system, the more likely that these technology will be adopted. Therefore, the main hypothesis was constructed to define the relationship between students' attitude to use e-learning and antecedent factors to use it in the educational system. In this study, attention is paid to those proposition which are utilized and converted to hypotheses that are easy to test and fit the context of e-learning in the educational system as follows;

Hypothesis H1: There is a relationship between Jordanian students' attitude towards using e-learning in the educational system and its antecedent factors to use it in Jordanian public universities.

The aforementioned research hypothesis $\mathrm{H} 1$ can be answered by testing the 5 sub hypotheses of $\mathrm{H} 1$; H1a to H1e;

Thus, the study has utilized Davis $(1989,1993)$ theoretical hypothesis in the context of using e-learning among Jordanian students in the educational system as follows;

Hypothesis Hla: There is a positive relationship between students' perceived usefulness of e-learning system and their attitude toward using it in the educational system in Jordanian public universities.

Hypothesis HIb: There is a positive relationship between students' perceived ease of use of e-learning system and their attitude toward using it in the educational system in Jordanian public universities.

In addition, Rogers (1995) proves that there is a relationship between innovation characteristics and the attitude to adopt it. This study focuses on two of these characteristics (TRIAL and OBSERV) as follows;

Hypothesis Hlc: There is a positive relationship between students' perceived trialability of e-learning system and their attitude toward using it in the educational system in Jordanian public universities.

Hypothesis H1d: There is a positive relationship between students' perceived observability of e-learning system and their attitude toward using it in the educational system in Jordanian public universities.

Moreover, many studies argue that there is a relationship between PBC and ATT (Ajzen 1991; Taylor and Todd, 1995), this study focuses on CSE relationship with attitude to adopt e-learning as follows;

Hypothesis Hle: There is a positive relationship between students' computer self-efficacy of e-learning system and their attitude toward using it in the educational system in Jordanian public universities.

Consequently, the research model and hypotheses have been designed based on the TAM, DOI, and DTPB. Therefore, adoption theories had proven the hypothesis on the relationship between ATT and BI (Davis, 1989; Ajzen, 1991; Rogers (1995); Taylor and Todd, 1995). This is follow to the second hypothesis of the study;

Hypothesis H2: There is a positive relationship between students' attitude toward use eleaning in the educational system and their behavioural intention to use it in Jordanian public universities. 


\section{Research Method and Data Collection}

The research method of this study has followed a quantitative approach. A survey was utilized to collect the data at one point in time. Therefore, a questionnaire was constructed to measure the factors including in the study. It is consisted of two parts; demographic factors of the students, and information about the factors included in the research model. The main dependent factor in this study is the BI to adopt e-learning which was measured by four items, in addition, students' ATT which was measured by four items adapted from many previous studies (Venkatesh and Davis, 2000; Davis 1993). Regarding to the independent, the PU and PEOU were measured by five items adapted from Venkatesh and Davis (2000). Consequently, TRIAL and OBSERV factors adapted from previous studies such as (Duan et al., 2010; Lee et al., 2011) and measured by three and four items respectively. Finally, CSE factor measured by five items and was adapted from (Compeau and Higgins, 1995; Dae-sik and Jeong-kyoum, 2013). In the other hand, the scale items were scored on a 7-point Likert scale that ranged from 1 (strongly disagree) to 7 (strongly agree). However, to ensure the validity of the questionnaire a panel of experts from Jordanian universities have reviewed it, and it was modified based on their suggestions and recommendations.

In relation to the data collection, the study deployed purposive sampling, judgement sampling in particular. Sekaran (2003) defined a judgment sampling as "the choice of subjects who are most advantageously placed or in the best position the information required". By using the judgment sampling, selection criteria must be developed, hence, the main criteria for the respondents sample is the students whom already finished the first year in their undergraduate study. Randomly questionnaires were distributed; about 350 questionnaires were distributed by the researcher and his colleagues in the universities. The returned 271, 18 were invalid, the total valid questionnaires were 253 , which is mean $72 \%$ response rate.

\section{Analysis and Results}

This part of the study presents the analysis of data, starting with the descriptive statistics by present the students' profile, followed by the reliability testing of the factors, the results of multiple regression and hypothesis testing are introduced. Table 1 presents the results of some personal information about the students in Jordanian public universities. This is including gender, level of study, and the major. The results present that $42 \%$ of the students were males and $58 \%$ were females. In relation of the level of study, $34 \%$ of the students were in the second year of their studies, $31 \%$ were in their third year, $35 \%$ were in their fourth year, however, the study exclude the students whom in the first year. Finally, the results showed that $60 \%$ of students from scientific faculties, and $40 \%$ from humanities faculties.

Table 1: The Respondents' Profile

\begin{tabular}{|l|l|l|l|}
\hline Factor & \multicolumn{1}{|c|}{ Item } & Frequency & Percentage \\
\hline \multirow{4}{*}{ Gender } & Male & 105 & $42 \%$ \\
\cline { 2 - 4 } & Female & 148 & $58 \%$ \\
\cline { 2 - 4 } & Total & $\mathbf{2 5 3}$ & $\mathbf{1 0 0 \%}$ \\
\hline \multirow{3}{*}{ Study } & Second year & 87 & $34 \%$ \\
\cline { 2 - 4 } & Third year & 78 & $31 \%$ \\
\cline { 2 - 4 } & Fourth year & 88 & $35 \%$ \\
\cline { 2 - 4 } & Total & $\mathbf{2 5 3}$ & $\mathbf{1 0 0 \%}$ \\
\hline Major & Scientific & 153 & $60 \%$ \\
\hline
\end{tabular}




\begin{tabular}{|l|l|l|l|}
\hline & Humanities & 100 & $40 \%$ \\
\cline { 2 - 4 } & Total & $\mathbf{2 5 3}$ & $\mathbf{1 0 0 \%}$ \\
\hline
\end{tabular}

On the other hand, the relationships between BI of individuals on innovations (as measured by TAM, DOI, and DTPB) were investigated using Pearson's product-moment correlation coefficient. In accordance, preliminary analyses were performed to ensure no violation of the assumptions of linearity, normality, and homoscedasticity. Hence, the results of the Pearson's correlation coefficients on the factors with students' ATT and their BI are displayed in Table 2. With reference to Table 2 there is a strong, positive correlation between the students' BI to use e-learning and the CSE variable $(r=0.671, p<$ $0.01)$ and their ATT with CSE $(r=0.636, p<0.01)$. Therefore, this result is supported the hypothesis H1e.

\begin{tabular}{|c|c|c|c|c|c|c|c|c|c|}
\hline Variables & $M$ & SD & IV1 & IV2 & IV3 & IV4 & IV5 & DV1 & DV2 \\
\hline IV1-PU & 4.73 & 1.16 & $(0.86)$ & & & 5.73 & 1.16 & & \\
\hline IV2- PEOU & 5.18 & 1.49 & 0.516 & $(0.88)$ & & & & & \\
\hline IV3- TRIAL & 5.54 & 1.03 & "0.164 & 0.191 & $(0.90)$ & & & & \\
\hline IV4- Obsev & 5.65 & 0.95 & *** 456 & . 400 & .362 & $(0.77)$ & & & \\
\hline IV5-CSE & 4.65 & 2.02 & ${ }^{* *} 0.645$ & $* .570$ & $* * 442$ & .385 & $(0.80)$ & & \\
\hline DV1-ATT & 4.75 & 1.63 & 0.610 & *** 0.542 & * 0.177 & 0.314 & 0.636 & $(0.78)$ & \\
\hline DV2-BI & 4.77 & 1.74 & ${ }^{* *} 0.581$ & *** 0.516 & *0.109 & 0.377 & ${ }^{* *} 0.671$ & 0.711 & $(0.84)$ \\
\hline
\end{tabular}

Sequentially, the result of students' BI with PU showed there was a strong positive correlation $(\mathrm{r}=0.581, \mathrm{p}<0.01)$ and with ATT $(\mathrm{r}=0.610, \mathrm{p}<0.01)$ which support the hypothesis H1a. As well as this, the relationship between students' BI and their perceptions on the e-learning PEOU with correlation $(\mathrm{r}=0.516, \mathrm{p}<0.01)$, and with ATT $(\mathrm{r}=0.542, \mathrm{p}<0.01)$ which support the hypothesis H1b. Besides, the association between the students' OBSERV of e-learning and their BI to adopt it is also positive $(\mathrm{r}=0.377, \mathrm{p}<$ $0.01)$, similarity with their students' ATT with the OBSERV $(\mathrm{r}=0.314, \mathrm{P}<0.01)$ which is support hypothesis H1d. In addition, the variable TRIAL is considered significant with BI $(\mathrm{r}=0.109, \mathrm{p}<0.01)$, and $(\mathrm{r}=0.177, \mathrm{p}<0.01)$ with ATT which is rejected hypothesis H1c. Finally, there is a strong relationship between students' BI to adopt e-learning and their attitude to use it $(\mathrm{r}=0.711, \mathrm{p}<0.01)$ which is support hypothesis $\mathrm{H} 2$.

The research model, which clarify the significance of the formative relationship between the technology characteristic factors, is drawn from the stepwise multiple regression analysis. However, a multiple regression was applied to measure the perception and the influence of the five extracted attributes on the students' attitude which is influences their behavioural belief to use it. Hence, research model factors PU, PEOU, TRIAL, OBSERV, and CSE are required to test the research model, in which the results of the analysis are displayed in Table 3. 
Promoting the Higher Education Excellence in Jordan ......

\begin{tabular}{|c|c|c|c|c|c|}
\hline \multirow{3}{*}{$\begin{array}{l}\text { Predictor } \\
\text { Variable }\end{array}$} & \multirow{2}{*}{\multicolumn{2}{|c|}{$\begin{array}{l}\text { Unstandardized } \\
\text { Coefficients }\end{array}$}} & \multirow{3}{*}{$\begin{array}{c}\text { Standardized } \\
\text { Coefficients } \\
\text { Beta }\end{array}$} & \multirow{3}{*}{$\mathbf{t}$} & \multirow{3}{*}{ Sig } \\
\hline & & & & & \\
\hline & B & Std.Error & & & \\
\hline Constant & 0.002 & 0.051 & & -0.036 & 0.971 \\
\hline CSE & 0.265 & 0.067 & 0.264 & $3.979^{*}$ & 0.000 \\
\hline PU & 0.206 & 0.064 & 0.205 & $3.197^{*}$ & 0.002 \\
\hline PEOU & 0.188 & 0.056 & 0.188 & $3.362^{*}$ & 0.001 \\
\hline OBSERV & 0.125 & 0.057 & 0.125 & $2.206^{*}$ & 0.028 \\
\hline TRIAL & 0.071 & 0.053 & 0.071 & 1.347 & 0.179 \\
\hline $\mathrm{R}:$ & 0.608 & & & & \\
\hline $\mathrm{R}^{2}:$ & 0.370 & & & & \\
\hline Adjusted $\mathrm{R}^{2}$ : & 0.357 & & & & \\
\hline \multicolumn{6}{|c|}{ Std error for estimate: 0.804} \\
\hline \multirow[t]{2}{*}{ Model Summary } & y $\quad$ DF & Analysis & & $\mathbf{F}$ & Sig of $F$ \\
\hline & & Sum of Squares & Mean Square & & \\
\hline Regression & 5 & 93.136 & 18.627 & 28.767 & 0.000 \\
\hline Residual & 245 & 158.640 & 0.648 & 1 & \\
\hline Total & 250 & 251.776 & & & \\
\hline
\end{tabular}

As seen in Table 3, the relevant statistical findings reveal that;

I. The regression equation is found significant $(\mathrm{F}=28.767, \mathrm{p}<0.001)$ and the accuracy of the regression model is supported by the examination of the residuals.

II. The standardized coefficient values for Trial is $\beta=0.071$ which is positive but insignificant at $\mathrm{p}<0.01$. Therefore, this factor is not supported in the research model in hypothesis H1c.

III. The standardized coefficients $\beta=0.264$ value for CSE are positive and significant at $\mathrm{p}<0.01$. As a result, this factor is supported in the research model.

IV. The standardized coefficient values for $\mathrm{PU}$ is $\beta=0.205$. It is positive significant at $\mathrm{p}<0.01$ so the result of this factor is supported the research model.

V. The standardized coefficients $\beta=0.188$ value for PEOU is positive and significant at $\mathrm{p}<0.01$, and therefore, it is supported in the research model.

VI. The standardized coefficients $\beta=0.125$ value for OBSERV is positive and significant at $\mathrm{p}<0.01$. Therefore, it is supported in the research model.

\section{Discussion of the Results}

This study has measured the factors that influencing the students' intention to use elearning system in the educational system in the Jordanian higher education institutions. Adoption theories such as TAM, DOI, and DTPB were used to develop the research model. The results found CSE has been significantly and positively influencing with the students' intention to adopt and use e-learning system in their educational process. This result is also consistent with the previous studies such as (Alenezi et al., 2010; Cheung and Vogel, 2013; Dae-sik and Jeong-kyoum, 2013; Lee, and Mao, 2016). This result means that the students will intend to adopt and use e-learning system if they have ability and skills to use computer technologies and its applications. In line with the previous literature, the PU is found to be significantly and positively affecting with the students' BI and their attitude to use e-learning (Park, 2009; Cheng, 2011; Tselios et al., 2011; Hsieh et al., 2014). Hence, the students will intend to use e-learning when they found it useful for them and helps them to perform their educational tasks and activities. Sequentially, the results showed a positive significant affect of the PEOU with students' BI and their attitude to use e-learning system. This result is suitable with the previous studies such as 
(Park, 2009; Cheng, 2011; Tselios et al., 2011; Hsieh et al., 2014). Therefore, students will intend to adopt and use e-learning system when they found it easy for them. Additionally, the results of this study are also consistent with the previous literature regarding the positively significant influence of the OBSERV factor by students to use educational technologies with their BI and attitude to adopt and use e-learning system (Duan et al., 2010; Lee et al., 2011; Sawang et al., 2013). This means the students who have advantages to visible for technologies used in education system in general, e-learning in particular, they have intent to adopt and use e-learning system.

On the other hand, the result of the hypothesis that not supported the research model represents the influence of the TRIAL factor with students' BI and ATT to use e-learning. The results showed there is insignificant relationship between the experiences and previous used of e-learning among the students and their BI to adopt and use it permanently. Hence, the previous trials of educational technologies are not important to the Jordanian students' intention to adopt e-learning. Few studies support this result such as (Olatukun and Igbinedion, 2009; Ntemana and Olatokun, 2012). However, there are many reasons for the result which is contrast with many studies were conducted in developed nation in the field of IS adoption. Culture of the Arab world is different from other cultures in developed nations and other developing countries, in addition, the lack of experimentation system of new technology, and the weakness of training systems in the Arab world are considered critical reasons to this result.

The last approved hypothesis is related to the positively significant relationship between students' attitude to adopt e-learning system and their BI to adopt and use it in their educational system. The findings are consistent with previous studies such as (Songkram, 2015; Truskolaska, et al., 2015). Therefore, students' intention to use e-learning will increase when they have a positive perception or feeling of favourableness towards using e-learning.

Based on the previous discussions, the main factors which are positively and significantly influence the students' intention to use e-learning are (CSE, PU, PEOU, and OBSERV). These factors could contribute in guiding the e-learning adoption and usage in Jordanian universities. In conjunction, the study gives benefits to the higher education institutions to develop and improve the teaching and learning process by using e-learning system. Consequently, the study also attempts to support the leaders of the higher education institutions a full image about the current status of e-learning system. Moreover, it helps the decision makers to determine which factors need support and which need treatment to encourage students to adopt the technologies in the educational system. As a consequence of this, the study could contribute in increasing the awareness and importance of the elearning and its applications to help the students in their education system.

\section{Conclusion and Future Research}

The study has contributed to a deeper understanding of the factors that affect students' intention to use e-learning system in the Jordanian universities. The Findings have provided and supported the higher education leader to enhance the higher educational system in the country. Five factors were explored as potential factors that influence the students' BI to adopt and use e-learning system. The research method was employed a quantitative approach by distributed a questionnaire to the students in Jordanian public universities. Consequently, the collected data was analyzed using Multiple Regression 
Analysis (MRA) to examine and measure the research hypotheses. Therefore, the findings showed that there was a positive significant relationship between CSE, PU, PEOU, and OBSEV, with the students' attitude and BI to use e-learning system. CSE considered as an important motivator and a predictor of its rate of adoption. However, these results were agreed with previous studies in this field in developed and developing nations. On the other hand, the TRIAL factor did not support the influence of students' BI to use elearning system. Different reasons for this result such as culture gap, the lack of experimentation system, and the weakness of training systems.

In relation to the future work, this study has pointed out that there is lack of this kind of studies in the Arab world, Jordan in particular. Therefore, the region needs to construct novel studies in this kind of research. Moreover, the study recommends a qualitative research method using a longitudinal study which could be used to support deeply understand the affect of these factors and identify new ones. In addition, encourage and promote to use e-learning from academicians, and the motivations of university management to support the usage of such educational technologies could be investigated in new studies. Finally, it would be useful to study the importance of the use of technologies in the educational system to enhance and improve the teaching and learning process, and further, add great value to students, academicians, and universities.

\section{References}

Ahmad, N., Tarmidi, M., Ridzwan, I., Hamid, M., and Roni, R. (2014). The Application of Unified Theory of Acceptance and Use of Technology (UTAUT) for Predicting the Usage of E-Zakat Online System. International Journal of Social Science Research, IJSR, 3(4), 63-67.

Ajzen, I. (1991). The Theory of Planned Behavior. Organizational behavior and human decision processes, 50(2), 179-211. doi: 10.1016/0749-5978(91)90020-T.

Ajzen, I. (2002). Perceived Behavioural Control, Self -efficacy, Locus of Control, and the Theory of Planned Behaviour. Journal of Applied Social Psychology, 32(1) 1-20.

Ajzen, I., and Fishbein, M. (1980). Understanding attitudes and predicting social behavior: Prentice-Hall. Englewood Cliffs. NY.

Alenezi, A. R., Abdul Karim, A. M., and Veloo, A. (2010). An empirical investigation into the role of enjoyment, computer anxiety, computer self-efficacy and internet experience in influencing the students' intention to use e-learning: A case study from Saudi Arabian governmental universities. Turkish Online Journal of Educational Technology,9(4),22-34.

Almarabeh, T., Majdalawi, Y. K., and Mohammad, H. (2016). Internet Usage, Challenges, and Attitudes among University Students: Case Study of the University of Jordan. Journal of Software Engineering and Applications, 9(12), 577.

Alshammari, N. (2014) The Use of Technology in Education to Improve Student's Reading Skills in Elementary Schools, Saudi Arabia. International Journal of Business and Social Science, 5, 69.

Al-Zaidiyeen, N. J., Mei, L. L., and Fook, F. S. (2010). Teachers' Attitudes and Levels of Technology Use in Classrooms: The Case of Jordan Schools. International Education Studies, 3(2), 211.

Amara, N. B., and Atia, L. (2016). E-TRAINING AND ITS ROLE IN HUMAN RESOURCES DEVELOPMENT. Global Journal of Human Resource Management, 4(1), $1-12$. 
Bandura, A. (2005). The primacy of self-regulation in health promotion. Applied Psychology: An International Review, 54(2), 245-254.

Baskerville, R.L. and Myers, M.D. (2002). Information systems as a reference discipline. MIS Quarterly, 26(1), 1-14. doi: 10.2307/4132338.

Chang, L., Mak, M. C., Li, T., Wu, B. P., Chen, B. B., \& Lu, H. J. (2011). Cultural adaptations to environmental variability: An evolutionary account of East-West differences. Educational Psychology Review, 23(1), 99-129.

Cheng, Y.-M. (2011). Antecedents and consequences of e-learning acceptance. Information Systems Journal, 21(3), 269-299.

Cheung, R., \& Vogel, D. (2013). Predicting user acceptance of collaborative technologies: An extension of the technology acceptance model for e-learning. Computers \& Education, 63, 160-175.

Compeau, D. R., Higgins C. A., (1995). Computer Self-efficacy: Development of a Measure and Initial Test. MIS Quarterly, vol. 19, no.2, 1995, pp. 189-211.

Dae-sik, K., \& Jeong-kyoum, K. (2013). Structural relationship among affective characteristics, cognitive characteristics, students' participation, and course-retaking intention in e-learning environment. International Journal of Smart Home, 7(6), 49-57.

Davis, F. (1989). Perceived usefulness, perceived ease of use, and user acceptance of information technology. MIS quarterly, 13(3), 319-340. doi: 10.2307/249008.

Davis, F. (1993). User acceptance of information technology: system characteristics, user perceptions and behavioral impacts. International journal of man-machine studies, 38(3), 475-487. doi: 10.1006/imms.1993.1022.

Demeke, W., Olden, A., and Nocera, J. A. (2016). Factors Affecting the Adoption of Information and Communication Technologies: Small Hotels and Tour Operators in Addis Ababa, Ethiopia. Libri, 66(2), 151-165.

Duan, Y., He, Q., Feng, W., Li, D., Fu, Z. (2010). A study on e-learning take-up intention from an innovation adoption perspective: A case in China. Computers \& Education, 55, 237-246.

Duțăa N. and Martínez-Rivera O. (2015). "Between theory and practice: the importance of ICT in Higher Education as a tool for collaborative learning," Procedia - Social and Behavioral Sciences, vol. 180, pp. 1466 - 1473, 2015. doi:10.1016/j.sbspro.2015.02.294

Dutta, S. and Mia, I. (Eds.) (2011). Global Information Technology Report 2010-2011: Transformations 2.0. Basingstoke: Palgrave Macmillan. Retrieved April 17, 2015 from, http://reports.weforum.org/global-information-technology- report/content/pdf/wef-gitr2010-2011.pdf.

Erwin, P. (2001). Attitudes and Persuasion. Hove, East Sussex: psychology press.

Gasaymeh, A. (2009). A study of faculty attitudes toward internet-based distance education: A survey of two Jordanian public universities. PhD Thesis, the College of Education, Ohio University, Ohio, USA.

Goodman, S., and Green, J. (1992). Computing in the Middle East. Communications of the ACM, 35(8), 21-25. doi: 10.1145/135226.135236.

Hsieh, L.-Y., Lu, Y.-J., and Lee, Y.-H. (2014). Using the technology acceptance model to explore the behavioral intentions toward blended learning. In D. Liberona and L. Uden (Eds.), Learning technology for education in cloud.MOOC and big data (pp. 195-203). Springer.

Information Technology Association-Intaj. (2010). Jordan's Information Society. Accessed July 23, 2010. Retrieved from, http://www.intaj.net (2016).

Jenkins, M. \& Hanson, J. (2003). E-learning series: A guide for senior managers, Learning and Teaching Support Network (LSTN) Generic Centre, United Kingdom. 
Kautz, K., and by Larsen, E. (2000). Diffusion theory and practice. Information Technology and People, 13(1), 11-26. doi: 10.1108/09593840010312726.

Khasawneh, M. (2015). Factors Influence e-Learning Utilization in Jordanian Universities-Academic Staff Perspectives. Procedia-Social and Behavioral Sciences, 210, 170-180.

Khasawneh, M, (2016). EVALUATION AND ASSESSMENT OF USING ELEARNING IN JORDANIAN UNIVERSITIES, MANAGERIAL PERSPECTIVE. Paper presented at the Proceedings of the ICERI2016 (9th annual International Conference of Education, Research and Innovation). Seville, Spain (14 - 16 NOV, 2016).

Khasawneh, M, and Ibrahim, H. (2012). A Model for Adoption of ICT in Jordanian Higher Education Institutions: An Empirical Study. Journal of e-Learning and Higher Education. IBIMA Publishing. http://www.ibimapublishing.com/journals/JELHE/jelhe.html. Vol. 2012, Article ID 877178, 10 page, DOI: 10.5171/2012.877178.

Lam T., Cho V., and. Qu H. L. (2007), 'A study of hotel employee behavioral intentions toward adoption of information technology, International Journal of Hospitality Management, vol. 26, no. 1, pp. 49-65.

Lee, Y. H., Hsieh, Y. C., \& Hsu, C. N. (2011). Adding innovation diffusion theory to the technology acceptance model: Supporting employees' intentions to use e-learning Systems. Journal of Educational Technology \& Society, 14(4), 124-137.

Lee, P. C., and Mao, Z. (2016). The relation among self-efficacy, learning approaches, and academic performance: an exploratory study. Journal of Teaching in Travel \& Tourism, 16(3), 178-194.

Liaw, S. S., and Huang, H. M. (2013). Perceived satisfaction, perceived usefulness and interactive learning environments as predictors to self-regulation in e-learning environments. Computers and Education, 60(1), 14-24.

Lu, H.K., and Lin, P.C.(2012). Toward an extended behavioral intention model for elearning: Using learning and teaching styles as individual differences. 2012 Consumer Electronics, Communications and Networks (CECNet) International Conference ,36733676.

Luftman, J., Bullen, C., Liao, D., Nash, E., and Neumann, C. (2004). Managing the information technology resource: Pearson Education.

Macharia, J., and Nyakwende, E. (2010). Vice-Chancellors Influence on Academic Staff Intentions to Use Learning Management Systems (LMS) For Teaching and Learning. Journal of Language, Technology and Entrepreneurship in Africa, 2(1), 220-230.

Ministry of Higher Education and Scientific Research (MOHESR). (2016). Retrieved from, www.mohe.gov.jo, 25 Aug, 2016.

Ntemana, T. J., \& Olatokun, W. (2012). Analyzing the influence of diffudion ofinnovation attributes on lecturers' attitudes toward inoformation and communication technologies. Human Technology, 8(2), 179- 197.

Olatokun, W. M., \& Igbinedion, L. J. (2009). The Adoption of Automatic Teller Machines in Nigeria: An Application of the Theory of Diffusion of Innovation. Issues in Informing Science and Information Technology, 6.

Othman, M. F. I. (2016). Barriers to the adoption of formal IT governance practice: A Malaysian case (Doctoral dissertation, Queensland University of Technology).

Park, N., Lee, K. M., and Cheong, P. H. (2008). University instructors' acceptance of electronic courseware: An application of the technology acceptance model. Journal of Computer Mediated Communication, 13(1), 163-186. doi: 10.1111/j.10836101.2007.00391.x. 
Park, S. Y. (2009). An Analysis of the Technology Acceptance Model in Understanding University Students' Behavioral Intention to Use e-Learning. Educational Technology and Society, 12(3), 150-162, http://dx.doi.org/10.1007/s00340-009-3513-0.

Qteishat, M., Alshibly, H., and Al-Ma'aitah, M. (2013). Factors Influencing the Adoption of E-Learning in Jordan: an Extended TAM Model. European Journal of Business and Management, 5(18), 84-100.

Qudais, M. A., Al-Adhaileh, M., and Al-Omari, A. (2010). Senior Faculty Members' Attitudes in Jordanian Universities towards Using Information and Communication Technology. International Arab Journal of e-Technology, 1(4), 135-141.

Ramirez, F. O., Byrkjeflot, H., and Pinheiro, R. (2016). Higher education and health organizational fields in the age of "world class" and "best practices". In Towards A Comparative Institutionalism: Forms, Dynamics and Logics Across The Organizational Fields of Health Care and Higher Education(p.35-57).Emerald Group Publishing Limited. Rogers, E. (1983). Diffusion of innovations. New York: Free Press.

Rogers, E. (1995). Diffusion of innovations (4 ed.). New York: Free Press.

Rogers, E., and Shoemaker, F. (1971). Communication of innovations: Across Cultural Approach (2 ed.): Free Press New York.

Sawang, S., Newton, C., \& Jamieson, K. (2013). Increasing learners' satisfaction/intention to adopt more e-learning. Education+ Training, 55(1), 83-105.

Schneberger, S. Amoroso, D.L. and Durfee, A. (2008). Factors that influence the performance of computer-based assessments: an extension of the Technology Acceptance Model. Journal of Computer Information Systems, 48(2), p.74.

Sekaran, U. (2003). Research methodology for business: New York: John Wiley and Sons, Inc.

Sharma U., and Jacobs K. (2016), "Predicting in-service educators' intentions to teach in inclusive classrooms in India and Australia," in Teaching and Teacher Education, vol. 55, April, pp.13-23.

Shiau, W. L., and Chau, P. Y. (2016). Understanding behavioral intention to use a cloud computing classroom: A multiple model comparison approach. Information and Management, 53(3), 355-365.

Singh, J. D. (2015). Higher Education in India-Issues, Challenges and Suggestions. CTE,(nd).

Songkram, N., Khlaisang, J., Puthaseranee, B., and Likhitdamrongkiat, M. (2015). ELearning System to Enhance Cognitive Skills for Learners In Higher Education. Procedia Social and Behavioral Sciences, 174, 667-673. http://dx.doi.org/10.1016/j.sbspro.2015.01.599.

Sooknanan, P. (2002). Attitudes and perceptions of teachers toward computers: the implication of an educational innovation in Trinidad and Tobago. Doctoral thesis, Bowling Green University, ProQuest Digital Dissertations.

Swaim, J. A., Maloni, M. J., Napshin, S. A., and Henley, A. B. (2014). Influences on student intention and behavior toward environmental sustainability. Journal of Business Ethics, 124(3), 465-484.

Talukder D. M. (2014), Managing Innovation Adoption: From Innovation to Implementation. Ashgate Publishing, Ltd.

Tarhini, A., Hone, K., Liu, X., and Tarhini, T. (2016). Examining the moderating effect of individual-level cultural values on users' acceptance of E-learning in developing countries: a structural equation modeling of an extended technology acceptance model. Interactive Learning Environments, 1-23. 
Taylor, S., and Todd, P. A. (1995). Understanding information technology usage: A test of competing models. Information Systems Research, 6(2), 144-176.

Tran, N. (2013). Evaluation in Distance Education and E-Learning: The Unfolding Model. Journal of Educational Administration, 51(1), 100-102. http://dx.doi.org/10.1108/09578231311291486.

Truskolaska, J., Luka, M., Toruj, N., Wrona, K., and Smagowska, P. (2015). E-Learning at the Polish University in the Opinion of Students. Procedia Social and Behavioral Sciences, 174, 3494-3499. http://dx.doi.org/10.1016/j.sbspro.2015.01.1063.

Tselios, N. K., Daskalakis, S., and Papadopoulou, M. (2011). Assessing the acceptance of a blended learning university course. Educational Technology \& Society, 14(2), 224-235.

Valsamidis, S., Kazanidis, I., Petasakis, I., Kontogiannis, S., and Kolokitha, E. (2014). ELearning Activity Analysis. Procidia Economics and Finance, 9, 511-518. http://dx.doi.org/10.1016/S2212-5671(14)00052-5.

Venkatesh, V., \& Davis, F.D. (2000). "A theoretical extension of the technology acceptance model: four longitudinal field studies. Management Science, 46(2), 186-204.

Walker, R., and Johnson, L. (2005). Towards understanding attitudes of consumers who use internet banking services. Journal of Financial Services Marketing, 10(1), 84-94. doi: 10.1057/palgrave.fsm.4770175. 